\title{
ВПЛИВ МІНЕРАЛЬНИХ ДОБРИВ НА ПОЖИВНИЙ РЕЖИМ ГРУНТУ ЗА ВИРОЩУВАННЯ ПШЕНИЦІ ТВЕРДОЇ ЯРОЇ
}

\section{Рецензент - доктор сільськогосподарських наук, професор П. В. Писаренко}

\begin{abstract}
Використання мінеральних добрив, особливо азотних, у помірних дозах $\left(\mathrm{N}_{23-45}\right)$ у посднанні з фосфорними та калійними дає можливість суттєво поліпшити поживний режим трунту. Доступними поживними елементами рослини забезпечуються в результаті мінералізації органічних сполук трунтовими мікроорганізмами і переходу мінеральних важкорозчинних речовин у розчинні. Це створює більш сприятливі умови для росту й розвитку рослин та підтримання родючості грунту на високому рівні. На кінець вегетаиії пшениці ярої відбувся перерозподіл нітратної й аміачної форм азоту.
\end{abstract}

Ключові слова: пшениия тверда яра, мінеральні добрива, поживний режим трунту, нітратна і мінеральна форми азоту.

Постановка проблеми. Сучасні сорти пшениці ярої мають високий потенціал урожайності (в дослідах до 5,0-5,5 т/га, в умовах виробництва - близько 3,0-3,5 т/га). Проте середній урожай за останні роки в умовах Лісостепу становив лише 2,0-2,5 т/га. Одна 3 причин невисокої врожайності - недостатнє вивчення умов ефективного застосування добрив 3 урахуванням рівня зволоження й забезпеченості грунту елементами живлення.

Виявлення закономірностей дії мінеральних добрив на родючість грунту та врожайність сільськогосподарських культур - важлива умова для розробки науково обгрунтованої системи удобрення. Найбільш сприятливі умови для досягнення високої продуктивності рослин, а також для підтримання родючості грунту на потрібному рівні, створюються за повного забезпечення їх елементами живлення. Основний запас поживних речовин грунту знаходиться у вигляді органічних і важкорозчинних мінеральних сполук. Так, у гумусових горизонтах понад $90 \%$ усього азоту, $60 \%$ фосфору, а також значна частина калію та мікроелементів перебуває у формі органічних речовин.

Аналіз основних досліджень і публікацій, у яких започатковано розв'язання проблеми.
Найбільш сприятливі умови для досягнення високої продуктивності рослин, а також для підтримання родючості грунту на потрібному рівні створюються за повного забезпечення їх елементами живлення [3]. Доступними ж поживними елементами рослини забезпечуються в результаті мінералізації органічних сполук грунтовими мікроорганізмами і переходу мінеральних важкорозчинних речовин у розчинні $[2,4]$.

Поживний режим грунту регулюється: надходженням поживних речовин у грунт завдяки внесенню добрив та азотфіксації; запобіганням втрат поживних елементів грунту за рахунок ї змиву і вимивання, росту бур'янів; правильним чергуванням культур; оптимізацією водного, теплового і повітряного режимів грунту, що активує його мікробіологічну активність i, відповідно, покращує доступність мінеральних елементів тощо. Встановлений достатньо тісний корелятивний зв'язок між кількістю внесених добрив і вмістом рухомих форм поживних речовин у грунті та врожайністю культури. Збільшення доз мінеральних добрив позитивно впливало на збільшення урожайності пшениці ярої за різних попередників. Встановлено також, що нагромадження у грунті рухомих сполук азоту, фосфору i калію зменшує негативний вплив погодних умов і сприяс стабілізації врожаїв $[6,9,11]$. Більшість дослідів щодо вивчення впливу мінеральних добрив на поживний режим грунту та врожайність пшениці ярої проведені у Поліссі й, частково, в умовах зрошення Степу $[7,10]$. Питання вирощування пшениці ярої в умовах Лівобережної частини Лісостепу ще залишається не дослідженим.

Зарубіжний та вітчизняний досвід свідчить, що головним напрямом успішного розвитку сільського господарства в Україні може бути економічно й екологічно обгрунтоване землеробство, невід'ємною частиною якого має бути інтегрована система захисту рослин, в якій певне місце займатимуть засоби хімічного захисту $[8,12]$.

\footnotetext{
* Керівник-доктор сільськогосподарських наук, професор Г. П. Жемела
} 


\section{СТОРІНКА МОЛОДОГО ВЧЕНОГО}

Не менш актуальним наразі є питання підвищення урожайності пшениці ярої. Необхідно насамперед розглянути вплив на врожайність елементів родючості грунту. Поряд 3 агрофізичними i біологічними елементами родючості суттєве значення мають агрохімічні якості грунту. Важливим у цьому плані $є$ наявність у грунті нітратного азоту, рухомого фосфору та обмінного калію. Десятирічними дослідженнями встановлено, що за підвищення в чорноземі вилугуваному нітратного азоту врожайність пшениці підвищується [1]. Збільшення рухомого фосфору та обмінного калію також позитивно впливало на ii врожайність [5].

Мета дослідження та методика його проведення. Метою наших досліджень було встановити дію мінеральних добрив на родючість грунту й ступінь мінералізації органічних сполук грунтовими мікроорганізмами, а також на перехід мінеральних важкорозчинних речовин у розчинні.

Основні експерименти виконувалися нами на дослідному полі Полтавського інституту АПВ ім. М. І. Вавилова. Вивчали вплив передпосівної обробки насіння мікробіологічними препаратами залежно від розрахованого балансовим методом фону мінерального живлення рослин на урожайність 3 т/га зерна. Варіанти закладалися на шести фонах мінерального живлення: 1) без добрив - контроль; 2) $\mathrm{N}_{45}$; 3) $\mathrm{P}_{45} \mathrm{~K}_{30}$; 4) $\mathrm{N}_{45} \mathrm{P}_{45} \mathrm{~K}_{30}$; 5) $\mathrm{N}_{23} \mathrm{P}_{23} \mathrm{~K}_{15}$;6) солома попередника $+\mathrm{N}_{10}$ на кожну тонну побічної продукції.

В основні фази розвитку рослин пшениці відбирали грунтові зразки 3 горизонтів 0-10 i 10-20 см для мікробіологічного та хімічного аналізів. Протягом вегетаційного періоду проводили спостереження за ростом і розвитком рослин, визначали площу листкової поверхні, чисту продуктивність фотосинтезу та фотосинтетичний потенціал посівів на всіх варіантах. Облік врожаю проводили комбайном у триразовому повторенні з облікової ділянки площею 25 м².

Результати досліджень. Наші дослідження показали, що у грунті на ділянках без добрив вміст доступних форм поживних елементів у фазу сходів пшениці ярої за сучасною класифікацією був зниженим за всіма поживними елементами в порівнянні з удобреними ділянками (див. табл.). Внесення азотних добрив, а також повного мінерального добрива збільшило сумарний вміст мінерального азоту на 30-45 \% відносно неудобрених ділянок. Азотні добрива в дозі $\mathrm{N}_{45}$ сприяли найбільш суттєвому підвищен- ню кількості сумарного мінерального азоту (на 57-64 \% по відношенню до контролю). У разі внесення різних доз азотних добрив на фоні фосфорно-калійних спостерігалося загальне збільшення як нітратного, так і аміачного азоту.

Для виявлення співвідношення нітратного й аміачного азоту в грунті визначали коефіцієнт, який вказує на ступінь використання мінерального азоту з грунту. Це дає можливість зробити припущення про більш високу активність асоціативної фіксації азоту на ділянках без внесення мінерального азоту.

Фосфор вносили у різних комбінаціях із азотними та калійними добривами. Це сприяло суттєвому збільшенню рухомих фосфатів у грунті, але в менших кількостях і процентних відношеннях, у порівняні з аналогічними дозами азотних добрив. Вміст фосфору на ділянках без застосування добрив становив 11,8 мг/кг грунту, при внесенні у вигляді фосфорно-калійного добрива - 13,5, повного добрива - 12,6-13,3 мг/кг грунту. Вміст доступного калію в грунті не мав чіткої залежності від внесених добрив. У процесі росту і розвитку пшениці ярої вміст доступних поживних речовин у грунті змінювався внаслідок їх використання рослинами на формування врожаю, мікробіологічної діяльності й інших процесів. Із наведених даних видно, що рівень вмісту доступних поживних речовин у грунті змінився в напрямі їх зменшення. Незважаючи на це, в основному збереглися закономірності їх кількісного співвідношення між ділянками досліду. Найменші показники сумарного мінерального азоту були на ділянках без застосування добрив, а також за внесення фосфорно-калійного добрива. Достовірно більшими у відношенні до контролю вони виявилися за внесення азотних добрив, а також повного мінерального добрива. На кінець вегетації пшениці ярої відбувся певний перерозподіл нітратної й аміачної форм азоту. Якщо у фазі сходів більшою була частка нітратної форми азоту, то в фазі достигання вона зменшилася до 5,3-8,9, відповідно, такий же показник мала частка аміачного азоту (6,8-9,9 мг/кг грунту). Щодо співвідношення нітратного й аміачного азоту в грунті, то він дещо зменшився, що можна пояснити послабленням мікробіологічної діяльності грунту внаслідок значних втрат вологи з верхніх шарів і активного використання нітратів. Водночас вищий рівень вмісту нітратного й аміачного азоту порівняно 3 контролем мав місце на ділянках, удобрених азотними добривами. 
СТОРІНКА МОЛОДОГО ВЧЕНОГО

Вміст елементів живлення в орному шарі трунту (0-30 см) у процесі росту і розвитку пшениці ярої залежно від удобрення (середнс за 2010-2011 рр.)

\begin{tabular}{|c|c|c|c|c|c|}
\hline \multirow{2}{*}{ Варіанти удобрення } & \multicolumn{5}{|c|}{ Мінеральні елементи живлення, мг/кг грунту } \\
\hline & $\mathrm{N}-\mathrm{NO}_{3}$ & $\mathrm{~N}-\mathrm{NH}_{4}$ & $\mathrm{~N}-\mathrm{NO}_{3} / \mathrm{N}-\mathrm{NH}_{4}$ & $\mathrm{P}_{2} \mathrm{O}_{5}$ & $\mathrm{~K}_{2} \mathrm{O}$ \\
\hline \multicolumn{6}{|c|}{ Фаза сходів } \\
\hline Без добрив & 10,5 & 6,4 & 1,64 & 11,8 & 15,6 \\
\hline $\mathrm{N}_{45} \mathrm{P}_{45} \mathrm{~K}_{30}$ & 17,9 & 8,7 & 2,06 & 13,3 & 16,3 \\
\hline Солома $+\mathrm{N}_{10}$ & 15,6 & 7,9 & 1,97 & 12,0 & 16,0 \\
\hline $\mathrm{N}_{23} \mathrm{P}_{23} \mathrm{~K}_{15}$ & 16,0 & 8,1 & 1,98 & 12,6 & 16,9 \\
\hline $\mathrm{N}_{45}$ & 18,1 & 8,7 & 2,08 & 11,9 & 15,8 \\
\hline $\mathrm{P}_{45} \mathrm{~K}_{30}$ & 12,0 & 8,8 & 2,05 & 13,5 & 16,8 \\
\hline \multicolumn{6}{|c|}{ Фаза колосіння } \\
\hline Без добрив & 8,8 & 7,3 & 1,21 & 10,7 & 14,1 \\
\hline $\mathrm{N}_{45} \mathrm{P}_{45} \mathrm{~K}_{30}$ & 15,3 & 8,0 & 1,91 & 12,8 & 16,0 \\
\hline Солома $+\mathrm{N}_{10}$ & 14,0 & 8,7 & 1,62 & 11,6 & 15,4 \\
\hline $\mathrm{N}_{23} \mathrm{P}_{23} \mathrm{~K}_{15}$ & 12,4 & 8,8 & 1,41 & 12,0 & 15,7 \\
\hline $\mathrm{N}_{45}$ & 15,9 & 9,9 & 1,60 & 10,2 & 14,6 \\
\hline $\mathrm{P}_{45} \mathrm{~K}_{30}$ & 11,8 & 10,1 & 1,50 & 11,9 & 15,9 \\
\hline \multicolumn{6}{|c|}{ Фаза достигання } \\
\hline Без добрив & 5,3 & 6,8 & 0,78 & 9,6 & 14,0 \\
\hline $\mathrm{N}_{45} \mathrm{P}_{45} \mathrm{~K}_{30}$ & 7,8 & 7,3 & 1,06 & 11,0 & 15,5 \\
\hline Солома $+\mathrm{N}_{10}$ & 8,6 & 8,2 & 1,05 & 10,7 & 14,6 \\
\hline $\mathrm{N}_{23} \mathrm{P}_{23} \mathrm{~K}_{15}$ & 8,6 & 7,9 & 1,08 & 10,8 & 14,9 \\
\hline $\mathrm{N}_{45}$ & 8,9 & 9,3 & 0,96 & 9,7 & 14,4 \\
\hline $\mathrm{P}_{45} \mathrm{~K}_{30}$ & 6,5 & 9,9 & 0,86 & 10,4 & 15,1 \\
\hline
\end{tabular}

У фазі достигання пшениці ярої кількість рухомих фосфатів у грунті зменшилася на всіх ділянках досліду. Вміст рухомого фосфору був максимальним за внесення повного мінерального добрива $(10,8-11,0)$, а також за застосування фосфорно-калійного добрива - 10,4 мг/кг грунту. Суттєвих закономірностей у змінах вмісту доступного калію в кінці вегетації пшениці ярої залежно від досліджуваних доз і співвідношень добрив не виявлено.

Оцінка стану поживного режиму грунту в кінці вегетації пшениці ярої дає можливість вказати наступне: найменші показники сумарного мінерального азоту були на ділянках без застосування добрив, а також за внесення фосфорно-калійного добрива; достовірно більшими по відношенню до контролю вони виявилися за внесення азотних добрив, а також повного мінерального добрива. На кінець вегетації пшениці ярої відбувся певний перерозподіл нітратної й аміачної форм азоту. Вищий рівень вмісту нітратного й аміачного азоту порівняно 3 контролем мав місце на ділянках, удобрених азотними добривами. Щодо кількості доступного калію в грунті - всі варіанти залишаються в групі високого вмісту.

Співвідношення нітратного i мінерального азоту в процесі росту й розвитку рослин змінювалося в бік зменшення показників. У фазі сходів пшениці ярої даний показник дорівнював 1,64 (без добрив) та 1,97-2,08 - за їх застосування в різних дозах, у фазі стиглості ці показники мали значення 0,78 та 0,96-1,08 відповідно.

Висновки: 1. Найбільш сприятливі умови для досягнення високої продуктивності рослин, а також для підтримання родючості грунту на потрібному рівні створюються за повного забезпечення їх елементами живлення.

2. Використання мінеральних добрив, особливо азотних, у помірних дозах $\left(\mathrm{N}_{23-45}\right)$ у поєднанні 3 фосфорними та калійними дає змогу суттєво поліпшити поживний режим грунту. Доступними ж поживними елементами рослини забезпечуються в результаті мінералізації органічних сполук грунтовими мікроорганізмами і переходу мінеральних важкорозчинних речовин у розчинні.

3. Застосування мінеральних добрив створює більш сприятливі умови для росту й розвитку рослин і підтримання родючості грунту на більш високому рівні. На кінець вегетації пшениці ярої відбувся певний перерозподіл нітратної та аміачної форм азоту. Вищий рівень вмісту загального азоту мав місце на удобрених ділянках. 


\section{БІБЛІОГРАФІЯ}

1. Антал Т. В. Продуктивність пшениці ярої твердої залежно від елементів технології вирощування в умовах північної частини Лісостепу України / Т. В. Антал, О. В. Малеончук // Матеріали наукової конференції професорськовикладацького складу, аспірантів та студентів НДІ агротехнологій та якості продукції рослинництва Національного аграрного університету. K., 2006. - C. 65.

2. Голик В. С. Яровая пшеница / В. С. Голик // Пшеница. - К. : Урожай, 1989. - С. 281-307.

3. Голик В. С. Создание сортов яровой мягкой и твердой пшеницы с высокими хлебопекарными и макаронными свойствами в Институте растениеводства им. В. Я. Юрьева / В. С. Голик // Наукові основи стабілізації виробництва продукції рослинництва. - Х., 2001. - С. 19-28.

4. Грииай А. Д., Камінський В. Ф., Романюк П. В., Свидинюк I. M. Чи є альтернатива інтенсивним технологіям вирощування сільськогосподарських культур // Землеробство. - 1994. - Вип. 69. C. 23.

5. Каленская С. М. Формирование продуктивности пшеницы яровой твердой при использовании удобрений / С. М. Каленская, Т. В. Антал // Вісник Білоцерківського державного аграрного університету. - 2008. - Вип. 52. - С. 82-85.

6. Кочмарский В. Яровая пшеница: адаптивность к стрессам / Кочмарский В., Соленая В., Хомен- ко С. // Зерно. - № 12. - 2011. - С. 14-17.

7. Лебідь $\Theta$. М. Зернове виробництво Дніпропетровщини: стан і перспективи розвитку / Є. М. Лебідь, В. С. Рибка, М. С. Шевченко [та ін.] // Бюл. Інституту зернового господарства. - Дніпропетровськ, 2006. - № 28-29. - С. 143-150.

8. Теоретичні та практичні засади виробництва та прогнозування якості насіння відповідно до міжнародних стандартів / [C. М. Каленська, Н. В. Новицька, Л. М. Гончар та ін.] // Наукові праці Півд. філіалу НУБіП України «Кримський агротехнологічний ун-т». - 2009. - Вип. 127. C. 228-232.

9. Жемела Г. П. Поліпшення якості зерна польових культур за допомогою використання добрив / Г. П. Жемела, Г. Г. Дуда // Удобрення польових культур при інтенсивних технологіях вирощування. - К. : Урожай, 1990. - С. 176-190.

10. Жемела Г. П. Токсичні елементи та їх вміст у грунті і зерні ярої твердої пшениці залежно від удобрення / Г. П. Жемела, О. В. Бараболя, В. М. Нечитайло [та ін.] // Зб. наук. праць Уманського ДАУ. - Умань, 2007. - Вип. 65. - С. 69-73.

11. Черников В. А. Агроэкология / В. А. Черников, Р. М. Алексахин, А. В. Голубев [и др.]. М. : Колос, 2000. - 536 с.

12. Чуб М. П. Влияние удобрений на качество зерна яровой пшеницы / Майя Павловна Чуб. М. : Россельхозиздат, 1980. - 69 с. 